\title{
To make or to serve-industrial specialization drivers of foreign subsidiaries in service and manufacturing sectors across
} agglomerations in a transition economy

\author{
Arkadiusz Mironko \\ Indiana University East \\ Phone: 765 973-8541 \\ ORCID ID: 0000-0001-5738-2925 \\ Email: amironko@iu.edu \\ USA
}

\section{ABSTRACT}

This paper examines the dynamics of the location patterns of the foreign direct investment(FDI)subsidiaries in manufacturing and service sectors across regions in a developing economy before and after the accession of the European Union in 2004. The data at the NUTS level 2 on regions in Poland is analyzed employing the revealed location advantage (RLA) index for industrial specialization (RLAis) of the regions. The study tests the concentration patterns of industrial sectors along with the industrial specialization level of regions' participating foreign enterprises across all regions of Poland. The findings allow answering for the presented hypothesis testing the level of industrial specialization across regions and its impact on narrowing industrial specialization, wages and the level of R\&D investment. The results determine that the location of foreign firms in service-related industries is concentrating mostly in the largest agglomerations with the presence of large markets and universities. While, also, several regions seem to be able to narrow their manufacturing specializations, they generally locate at, or near, the legacy centers of those industrial sectors. This provides answers for, and confirms the raised hypothesis and generally follows the existing theoretical path of the developed economies. The study, also, shows that Polish regions attracting a higher number of foreign service-related investments also seem to increase their industrial specialization in select manufacturing sectors that can increasingly attract R\&D investment.

\section{KEYWORDS: foreign direct investment (FDI), service, manufacturing, the EU transition}

\section{JEL: F04, F63; J38}

\section{Introduction}

Since the1990s global flows of foreign direct investment (FDI) to developing nations have grown significantly. In the case of the European Union (the EU), the countries which entered the block in 2004 became beneficiaries of this trend. A change in the composition of economic activity has also taken place during the period (Sinn, 2004; Bevan and Estrin,2004). A subsequent increase in the service sector to a dominant economic element for many countries has taken place (Miles,2005). Although manufacturing sectors continue to enjoy exploring regional and local efficiencies and resources across the globe making it a dynamic part of the global economic transformation for developing nations. According to the UNCTAD 2015 report around two-thirds of global FDI stock is now in the service-related industries with only one third in manufacturing sectors, this is an important trend that is closely watched and researched.
In the study by Ellison and Glaeser (1997), the research of the FDI flows demonstrates that firms tend to agglomerate their activities in geographic clusters. The propensity of foreign subsidiaries to agglomerate varies by the type of economic activity (Alcacer,2006). This offers a background where the new firms entering a country face a heterogeneous landscape of the host economy and are to choose as to the location of their operations. Similarly, according to the study of Crescenzi and Iammarino (2016) corporate networks have significantly changed regional connectivity and interdependence of firms around the world. Networks of foreign subsidiaries have created spiky geographies and uneven regional development. According to their study the presence of global 'gatekeepers', firms with innovative and institutional capabilities, allowed to build new advantages. Some of the advantages for foreign firms extend beyond assets and are within the innovation realm (Rugman, and Verbeke, 2003). Overall FDI is of particular importance to transition economies that rely on the flow of FDI not only as capital but 
also as a source of knowledge, know-how, and technology access. Hence, a dynamic movement of foreign direct investment into the regions providing advantages sought-after by foreign firms subsequently promotes, over time, the formation of clusters able to support economic activities requiring the higher level of skills (Feldman, Francis, and Bercovitz, 2005, Cooke, 2001, among others). Furthermore, existing industrial centers tend to attract more specialized investment into them (Florida, 2005). Such regional industrial specialization can be a supportive element in attracting further foreign investors hence promoting the economic growth of the regions.

While FDI in the manufacturing sectors in Poland is studied already there is little focus on service-related FDI at the sub-national level of regions in Poland. This study will seek to contribute by answering the question whether the regions and cities across Poland, a transition economy, can attract a higher grade of foreign direct investment both in the manufacturing and in-service industries before and after the accession of the EU (Resmini,2000; Bevan and Estrin,2004).

Further, this study will focus on the location choice of foreign investment within Poland based on the manufacturing and service sectors of the investment between existing and arising centers of economic activity within the country. The preparatory period before entry to the EU has created a broader opening of economic activity (Cassimati,2003) and therefore also the attraction of foreign investment. This work will contribute to the studies of this period, as well as, the years immediately after Poland has joined the EU. The analysis of the period between the years 2000 and 2006 allows us to see the impact of joining the EU, a large trading block, on the regional industrial activity with the regions in Poland based on the select economic factors. The results will provide a closer look at the location and sectoral dynamic of foreign investment during the period immediately before and after the EU accession by Poland.

Additionally, the analysis presented here will help to determine which agglomerations and regions exhibit industrial strengths and whether industrial specialization patterns emerge within the studied period. Economic centers developing industrial specialization will be viewed here as drivers of new investment and economic strength. Moreover, the combination of industrial strength and ability of industries within agglomerations to attract investment in R\&D may signal the region's ability to develop further. As much of the research on the subject suggests that the most important drivers of global FDI are the market size of the agglomeration and its industrial specialization level-which tend to describe the benefits when firms and industry networks locate near one another (Porter, 2000).

This paper will also aim to determine the level of concentration of manufacturing and service-related activities by foreign firms across regions in Poland, as well as a test on which economic factors influence the decision of the foreign investors in selecting locations to settle their operations in regions across the host country. Both theoretical and empirical contributions of this paper will be relevant to the foreign investors and managers considering entering the market as well host nation policymakers at national, regional and city levels attracting the investment into their territory.

The next section will provide a theoretical analysis and will introduce the hypothesis. The methodology and data description is next, and the discussion of the results is followed by a summary concludes.

\section{Sectoral location determinants}

The composition of foreign direct investment entering the Central and Eastern European (CEE) countries over the economic transition period studied here is changing. According to the study of Sass and Fifekova (2011), among others, the countries of the Central and Eastern Europe show a growing potential for attracting foreign direct investment in service-related industries. Studying the composition of foreign investment in the Czech Republic, Hungary, Poland, and Slovakia, Sass and Fifekova (2011) concluded that the CEE countries are becoming increasingly popular destinations for service-related offshoring and outsourcing activities mainly due to the availability of skilled labor, which possesses strong foreign language skills, low-cost, well-developed infrastructure, political stability, and proximity to the Western European countries.

This finding supports the trend where foreign subsidiaries seeking location-specific resources and efficiencies which are well identified in the eclectic paradigm through which Dunning (1977) selected the elements present in a host economy that would attract foreign direct investment. The three elements of the eclectic paradigm (OLI model) are associated with ownership advantages-O, where investing company would have a competitive advantage related to access to highly trained and skilled workforce technology or natural resources; a location advantages-L, where newly selected host location would offer greater benefit than home country locations; and internalization advantages-I, where investing companies would rather exploit opportunities in the host 
economy on their own rather than through a variety of licensing agreements with host locale firms (Dunning and Lundan,2008). The paradigm reflects the motivation of foreign companies and what the locations have to offer, therefore, making them attractive hosts for foreign investment.

The continually internationalizing system of economic activity in manufacturing and service sectors (Dunning and Narula,2005) impacts also developing economies that increase their effort to attract service related FDI. Especially when the host countries are able to offer supportive infrastructure, and other relevant conditions and its internal economy is able to afford more and more servicerelated consumption. As such countries with large internal markets and with proximity to the external markets, like access to the EU common market, have the potential to be attractive to service focused investment.

Despite the challenges in the early stages of the economic transition such as the "shock therapy", the transformation of Poland into a free market economy seems largely successful (Mickiewicz \& Baltowski,2003). Until early 1990s Poland along with other Central European nations, the Czech Republic, Slovakia, and Hungary among others, followed the path of central governance, which also included economic activity (Stark,1994). Some agglomerations, especially those formed near regional capital cities, such as Warsaw, Poznan, Lodz, Katowice, and Wroclaw had existing centers of economic activity, which often became bases of the new economic development. Some of the agglomerations managed to leverage the presence of the legacy industries to attract foreign investment and develop their existing industrial bases, while other regions, especially those along the eastern periphery, and some along the west as well, were successful to a lesser extent.

The economic geography research indicates that concentration of economic activity supports the economic growth in the region (Krugman,1991; Porter,1992; Fujita, Krugman and Venables,1996). Here, a region will be viewed in terms of geographic sub-regions within a country, generally with a specific focus on an agglomeration surrounding a key city as a nexus of economic activity for the region. The location decisions made by foreign investors entering the country are very important to the pace of development of the host regions within that country. Such choices are often based on the existing industrial specialization of the host regions and the level of presence of the foreign direct investment in those regions, among other factors. Also, an important element in the decision-making depends on the industrial sector of the incoming investment and where it finds supporting infrastructure and the ecosystem for its either manufacturing or service related activities (Blomström, Kokko, and Mucchielli, 2003). Furthermore, the earlier research also recognized that firms tend to locate according to their industrial sector (Cantwell and Piscitello, 2002; Iammarino and McCann,2006; Mironko,2014). The research in the area is focusing on the fact that the host locations tend to increasingly specialize in "fine-sliced" activities, which focus its specialization as the activities of multinational corporations are adjusting due to the rapidly moving innovation process (CanoKollmann et al,2016). Such a process speeds up innovation and is specifically pronounced in locations with existing highly connected networks (Cowan and Jonard, 2004).

\subsection{Location drivers of foreign subsidiaries on the industrial specialization of the regions}

The research on economic theory generally agrees that the proximate availability of a diverse set of business services is important for the economic growth of regions (Markusen, Rutherford, and Tarr,2000). According to the study of Bevan and Estrin (2004) at the earlier stage of the accession of the European Union new host country risk proved to be not a significant factor in FDI location choice. The remote locations within those countries, however, were not the primary locations selected by foreign subsidiaries locating within those countries. Such is also shown by the studies of regions in Hungary by De Simone and D'Uva (2016), in the Czech Republic by Schäffler, et al in (2016), and in Poland by Chidlow, et al, (2009) among others.

Earlier studies also indicate, the subsidiaries of multinational corporations generally locate according to industrial specialization, especially in the manufacturing sector (Dunning and Lundan,2008). This study will test whether similar industrial concentration can also be observed in the service industry sectors across regions in developing economies as well.. Based on the studies of Dunning in 1998 and 2005 economic factors present in particular regions and their future potential, as well as the availability of technology and natural resources, are determining factors for attracting FDI in specific sectors - service or manufacturing. Hence the following hypothesis is raised:

H1. The economic regions in Poland narrow their industrial specialization based on manufacturing and service criteria. 
2.2 The regional specialization of industries and attraction of new FDI

It is widely recognized that changes in technology and competition have diminished many of the traditional roles of locations (Porter,2000) nevertheless the role of industrial clusters and corporate networks remains a key component in corporate, national, and regional (sub-national) economic growth strategy. Many studies highlight the increasing complexity of economic activity and therefore place more importance on the role of clusters of corporate networks. The co-location of firms within the same industry provides access to industryspecific resources as well as knowledge (Marshall,1920; Krugman,1991). In such a way the findings of Saxenia(1994) determine that companies in Silicon Valley, Route 128 near Boston, and Michigan auto-cluster each have a defined industrial specialization focus which allows them to attract firms in their own and related sectors. This may also indicate that concentration of industry alone in a region is not sufficient to attract foreign investment, while other factors may seem to be more important in the decision making process, such as access to necessary, especially immobile resources.

As global economic conditions are constantly changing MNCs are in constant search for more knowledgeintensive capabilities. The countries and regions within them use different strategies to demonstrate the competitive advantage of locations for a specific type of industries leveraging their existing industrial base, workforce, and other economic advantages they may offer. The ability to attract new firms into the regions could be an indication of cluster development or adding to the existing knowledge base. A cluster formation generally also manifests itself in the ability to attract firms in the same or related industry into the region. Therefore the following hypothesis will be tested here:

\section{H2. Increasingly specialized agglomerations in Poland} attract new foreign investors in the narrowing industrial sectors.

\subsection{Regional Industrial specialization development and its impact on wages in Poland}

Often concentration of firms in a particular industry puts pressure on the supply of specialized labor, hence subsequently increasing labor costs. This, in turn, may prevent prospective investors from moving into the region, especially those who seek effects from labor cost efficiencies as done in the studies on the OECD countries by Noorbakhsh, Paloni, and Youssef (2001) and Southeast European countries by Botrić and Škuflić (2006). Also, the study of Lipsey and
Sjoholm (2001) examining the pay patterns of foreign firms in Indonesian regions reveal that higher presence of foreign firms leads to higher wages in indigenous businesses. They also find that foreign subsidiaries pay higher wages than locally-owned companies which means that higher foreign firm presence seeking specialized workforce raises the general wage level in a region and industry. This outcome, generally, adversely affects local businesses. Several studies conclude that foreign enterprises offer higher wages, hence, resulting in the transition of the workforce from domestic enterprises into foreign subsidiaries (Markusen, Rutherford, and Tarr,2000). The same study analyzing wages in the skilled labor sectors determined that the more foreign firms enter the domestic market the more the real wage of domestic skilled workers increases as well.

Further, the study of Porter (2000) finds that the strength and robustness of local clusters significantly impact the performance of regional economies. Regional wage differences are dominated by the relative performance of the region in the clusters in which it has positions; in the case of this study all regions in the national economy and their relative strengths are considered.

Additionally, the studies of Hanson (2001) and Mironko (2018) show that individual wages are increasing where the education level of the workforce is greater, which is consistent with localized human- capital externalities. This background will serve for testing of the following hypothesis:

\section{H3. The regions exhibiting an increased level of} service focused FDI also offer higher wages.

\section{Investment in $R \& D$ \\ 2.4 The Industrial Specialization of Regions and}

Generally, the performance of regional economies is strongly influenced by the strength of local clusters and the vitality and plurality of innovation (Porter, 2003). Foreign firms are also frequently seen as sources of funding and R\&D activity (Cantwell,1991). The success of R\&D activity and investment in it, however, requires the absorptive capacity of the host location (Lipsey and Kravis,1985; Blomstrom,1991). In both practical and theoretical terms investing MNCs become a vital source of building new industrial capabilities within regions of the host economies by improving the quality and reliability of local infrastructure and absorptive capacity of industries within the regions, including R\&D. The linkages and complementarities that develop between the firms in a region, even when only loosely developed, improve productivity and innovation in the firms within clusters (Cantwell,1991a; Porter, 
2000). Therefore it can be expected that the higher the industrial specialization of FDI in a region the higher should be the propensity to spend on $R \& D$.

The service industry as the generally younger industry relies on different locational factors for its economic development. It also tends to be a Greenfield type of investment (Head, Ries, and Swenson,1995). Uninterrupted access to information and communication technology as well as the skilled workforce can be an instrumental aspect of regional adaptation, and knowledge creation and spillover therefore also providing additional benefit to local firms present in the area. The ability to innovate and benefit from knowledge transfer networks is also measured in the amount of $R \& D$ investment (Tsai, 2001). This is an important factor contributing to a firm's ability to innovate, attract and utilize necessary knowledge, technology, and skilled workforce. Hence the following hypotheses are proposed here:

H4. The regions with a higher level of industrial specialization of FDI have increased investment in $R \& D$.

This study is expected to show the service and manufacturing industries investment location patterns across regions within a developing economy before and after the systemic change, accession into the EU, and offer insights as to the industrial specialization patterns of foreign firms locating across regions within Poland for the period. Also, the ability to innovate by foreign firms will be explored here. Therefore, infrastructure such as information technology and the skilled workforce are key components of attracting new investments and their successful adaptation in the cluster. The narrowing industrial specialization of the regions increased wages, and investment in R\&D, along with increased FDI entry can make it harder for the domestic firms to operate and complete.

\section{Data selection and methodology}

The data used in this research is structured according to the Nomenclature of Territorial Statistics (NTS) and based on the European Nomenclature of Territorial Units of Statistics (NUTS). The NTS nomenclature follows the three-tier division of the country into voivodships (the equivalent of a state or a province)-NTS 2, powiats and gminas being sub-units of the previous unit indicated by NTS 3 and 4. The data used for this research is at NTS Level 2, reflective of the presence of foreign firms within regions - voivodships. The regional level data at NTS Level 2 covers 16 regions, which Poland adopted in the year 2000 .

The data set includes firm-level information on the industry in which the subsidiary is participating in along with the host city and host region in Poland. An important distinction of the period of the study covers the period before Poland's entry into the European Union in 2004 and immediately after. The data covers the period from 2000 to 2006. This period gives an additional dimension to the investment patterns, which are expected to be revealed here.

The panel data set was identified and selected from foreign direct investment organization in Poland run by the Foreign Investment Department at the Polish Investment and Trade Agency (PITA) which collects information on foreign firms investing in Poland. The data reflects information on foreign investors across all regions in Poland reflecting over 800 firms in the year 2000 to nearly 1200 firms in 2006. The information contained is a firm's name, the location of investment in Poland, and the industry in which it operates along with sub-sector of the activity. The majority of firms are medium size foreign enterprises investing in Poland with several of large firms participating. The included firms cover 27 industries in both the manufacturing and service sectors. The firms are disbursed across all 16 regions - voivodships in Poland. 


\begin{tabular}{|c|c|c|c|c|c|c|c|}
\hline \multicolumn{8}{|c|}{ Number of Foreign firms by region } \\
\hline Region \Year & 2000 & 2001 & 2002 & 2003 & 2004 & 2005 & 2006 \\
\hline Dolnośląskie & 66 & 70 & 79 & 78 & 94 & 92 & 95 \\
\hline $\begin{array}{l}\text { Kujawsko- } \\
\text { Pomorskie }\end{array}$ & 21 & 18 & 18 & 20 & 26 & 19 & 24 \\
\hline Łódzkie & 47 & 43 & 54 & 49 & 65 & 65 & 68 \\
\hline Lubelskie & 15 & 16 & 13 & 13 & 16 & 17 & 16 \\
\hline Lubuskie & 15 & 21 & 19 & 20 & 24 & 22 & 22 \\
\hline Małopolskie & 35 & 35 & 41 & 38 & 45 & 41 & 42 \\
\hline Mazowieckie & 277 & 328 & 382 & 373 & 411 & 422 & 427 \\
\hline Opolskie & 16 & 16 & 17 & 18 & 20 & 22 & 22 \\
\hline Podkarpackie & 20 & 25 & 25 & 25 & 28 & 27 & 29 \\
\hline Podlaskie & 8 & 7 & 8 & 9 & 11 & 11 & 9 \\
\hline Pomorskie & 38 & 38 & 45 & 45 & 51 & 53 & 52 \\
\hline Śląskie & 60 & 56 & 59 & 74 & 81 & 86 & 89 \\
\hline Świętokrzyskie & 13 & 13 & 12 & 12 & 15 & 13 & 13 \\
\hline $\begin{array}{l}\text { Warmińsko- } \\
\text { Mazurskie }\end{array}$ & 11 & 10 & 10 & 12 & 13 & 13 & 13 \\
\hline Wielkopolskie & 92 & 92 & 97 & 94 & 109 & 107 & 107 \\
\hline $\begin{array}{l}\text { Zachodnio- } \\
\text { pomorskie }\end{array}$ & 17 & 19 & 19 & 23 & 24 & 33 & 31 \\
\hline $\begin{array}{l}\text { Total number of } \\
\text { foreign firms }\end{array}$ & 886 & 906 & 978 & 996 & 1,101 & 1,150 & 1,091 \\
\hline Total viable & 751 & 807 & 898 & 903 & 1,033 & 1,043 & 1,059 \\
\hline $\begin{array}{l}\text { Firms with } \\
\text { incomplete data }\end{array}$ & -135 & -99 & -80 & -93 & -68 & -107 & -32 \\
\hline
\end{tabular}

Source: Based on panel data obtained from Polish Investment and Trade Agency and the author's own calculation

\subsection{Methodology}

The panel data on FDI in Poland reflects the level of the presence of foreign firms across regions in the absolute terms. To determine the relative level of strength and help to explain the raised questions the Revealed Technological Advantage (RTA) index will be used here. The model was first applied by Soete (1987) and further developed by Cantwell (1989, and elsewhere). The adopted revealed location advantage (RLA) index method will help to equalize the measure for industrial specialization between regions. Subsequently, the results of the index will allow comparing heterogeneous regions within the country.

Without its application, a relative comparison of the strengths of regions from the primary data would be quite challenging, as for small regions having even lower levels of actual
FDI activity can be very important to their regional economic development.

Furthermore, the regional Industrial Specialization (RLAis) index measure will also allow normalizing the difference in industrial specialization between regions with high and low numbers of participating foreign firms. In a similar fashion following the research of Ergas (1986), Soete (1987) used the method to compare the growth rates of various size economies and to determine their influence level on small and large countries. Here following Soete, this analysis is also being expected to show small regions as being more specialized than larger regions.

The data on foreign firms in each industry sector present in each region will be used herein the proposed model to 
determine regional industrial specializations. The Revealed Location Advantage for industrial specialization RLAis will be calculated to reveal the strengths in the industrial trajectory of each industry in each region in the following way:

$$
\text { RLAis }=\frac{\text { Fyat } / F a t}{\text { Fyt } / F t}
$$

\section{Equation 1: Regional Industrial Specialization (RLAis) index of foreign firms}

To calculate the reveled location advantage index measure for the foreign firms' industrial specialization (RLAis) foreign firms in the industry are denoted by $y$, the region is $a$, and a year by $t$. The index level measure of the presence of the foreign direct investment across regions in Poland will determine the strengths of regions in attracting of foreign direct investment into them. Also, the level of industrial specialization for participating sectors across regions will be revealed from the analysis. This follows the study of the location of the US outbound FDI by Blonigen, et al, (2007) and by Djankov and Hoekman (2000) in Czech enterprises, which find that the relationship of traditional determinants of foreign direct investment is surprisingly robust in terms of capturing spatial interdependence.

Additionally, RLAis results for foreign subsidiaries will help to determine the relationship in attraction or deterrence effect for foreign subsidiaries in participating industries across regions. The adopted model will determine the level of presence of foreign firms across regions in Poland by measuring the industrial concentration of firms in the industrial sectors in each region. The result will help to answer the raised hypothesis. The RLAis index measure above 1 indicates the industrial specialization strength and the index measure below 1 indicates weakness.

The econometric method used here will give a good picture of the spatial location of foreign firms across regions in Poland. The method will not provide direct reasons behind the location choice of FDI across regions within the country. This will be remedied by testing additional variables via linear and multiple regressions modeling to reveal additional motives for the location $\mathrm{s}$ choice by foreign firms investing in Poland. Additional variables are examined here by use of correlation coefficients method and test whether the regions with a higher level of FDI in the service sector also see higher wages and increasing investment in $R \& D$ in the service sector.

Further, to determine the effect of the accession of the EU on the FDI flows into the regions the difference-indifferences (DID) econometric technique will be used. The cross-section data from treatment and control groups for an after the intervention period to obtain an estimate of a causal effect. DID will be implemented as an interaction of variables across the period in a regression model using Excel. It is presented as:

$\mathrm{Y}=\beta 0+\beta 1 *[$ Time $]+\beta 2 *[$ Intervention $]+\beta 3 *[$ Time* Intervention $]$ $+\beta 4 *[$ Covariates $]+\varepsilon$

Where the data for FDI presence in regions in years before and after the accession of Poland into the EU will denote time and data for the year 2004 will denote the intervention year.

Table 2. Coefficient measures for DID

\begin{tabular}{lcccc}
\hline & Coefficients & Standard Erro & t Stat & P-value \\
\hline Intercept & -1.689 & 0.852 & -1.984 & 0.071 \\
Year 2004 & 0.502 & 0.232 & 2.164 & 0.051 \\
Year 2005 & 0.645 & 0.377 & 1.711 & 0.113 \\
Year 2006 & -0.246 & 0.447 & -0.551 & 0.592 \\
\hline \multicolumn{1}{c}{ Regression Statistics } & 0.9996 & & & \\
\hline Multiple R & 0.9992 & & & \\
R Square & 0.9991 & & & \\
Adjusted R Square & 2.7212 & & & \\
Standard Error & 16 & & & \\
Observations & & & & \\
\hline
\end{tabular}


Further, control variables considered here relate to the level of wages and investment in R\&D and reflect industrial absorptive capacity and innovation capability of the regions. To answer for the proposed hypothesis data on regional investment in research and development will be used. The test will be designed by the use of the correlation coefficient between the select variables. Additionally, the outcome of this variable across of the nation's regions will be considered in terms of both private and public investment in R\&D. This result should create a picture of industrial strengths in industries which exhibit strength in RLAis index measure. Many cluster advantages also apply to research and development as well as production activity within the cluster (Porter, 2000; Cooke, 2001). The results of this analysis will allow developing a picture of the industrial strength across regions. Additionally the results will indicate the industrial specialization pattern development across the country. This will signal the regional industrial specialization development which can be interpreted as a regional strength. Finally, the results of the analysis of the investment in R\&D level and its correlation with industrial specialization will provide insights into the region's potential for absorptive capacity and innovation.

\section{Analysis of the results}

The goal of this paper is to examine the dynamics of the location patterns of foreign direct investment subsidiaries in manufacturing and service sectors across regions in Poland adding here to the subject matter research on developing economies. The analysis presents relative industrial sectors concentration patterns along with industrial specialization level of regions' participating foreign subsidiaries across all regions of Poland. The findings presented in Appendix 1 allow to determine that the location of foreign firms in service-related industries are concentrating mostly in larger agglomerations with the strong presence of large markets and universities, the source of skill workforce. Where increased industrial specialization in a cluster is observed this finding can be understood here as a potential for the attraction of further FDI into the clusters (Narula and Dunning,2000) and lead to regional industrial specialization development.The industrial specialization patterns in the developing economies generally reflect existing locational strengths of the industrial activity in an agglomeration or a cluster.

Answering for the hypothesis one, during the studied period the regions in Poland tend to narrow their industrial specialization in the regions that exhibit existing industrial strengths. For the majority of the regions, the revealed industrial specializations are in the manufacturing sectors with only a small number of service-related specializations of financial intermediation services at the RLAis level over 2.0 for all years are observed in Mazowieckie region. For many of the regions, the existing industrial strengths are the result of the legacy industries, the remnants of the centrally planned economy. These existing strengths form a base for new economic activity and may help further the industrial specialization of the regions going forward. Here the majority of the regions seem to be narrowing their RLAis measures for select manufacturing sector industries, therefore, confirming the H1.

Further, the data analysis reveals that regions which develop industrial specialization also tend to attract new foreign investors in the same industry into the region. This tends to further narrow industrial specialization of many regions into a fewer number of industries demonstrating RLAis strengths confirming $\mathrm{H} 2$. While industries which are losing their RLAis strength often disappear or give place to new, frequently, higher value-added industries, like in the case of diminishing strengths of manufacturing of food products and increasing strength of manufacturing of rubber and plastics in Malopolskie region. Also, analyzing the participation of foreign firms across industries in the regions, the new entering firms show involvement in a broader number of industries. Few exceptions are small peripheral regions, such as Podkarpackie, which are able to attract more firms within fewer industries therefore also indicating the potential for industrial specialization. Such concentration of firms in select industries shows increasing RLAis index measure as well.

The results of the regression between RLAis and market size and wages presented in Appendix 2 show that some foreign investors in service-related industries establish their operations in primary locations which have largest populations, markets and offer the best infrastructure along with access to workforce including talent graduating from numerous local universities. As foreign firms in manufacturing sectors generally choose locations which offer a lower cost of labor, hence giving a reason to conclude that the reason behind the investment may be to seek efficiencies from skilled labor and factors which supports lowering the operating costs. This follows the findings done in the study of Sass and Fifekova (2011) which indicate that some foreign investment firms in service industries seek efficiencies offered by remote locations and are not necessarily focused on serving local market alone. Although in the case of Polish regions in the period studied here not all peripheral regions seem to be able 
to attract the investment at the increased rate such as Podlaskie in manufacturing of wood and wooden products, one of its main industries, with correlation coefficient measure at 0.110 .

Concerning the hypothesis four, testing the impact of strength in service FDI on wages across industries shows that wages are not correlated with industrial specialization strength in service industries represented. This indicates that higher wages in the regions with established RLAis strengths in service industries are not posing as a deterrent for new foreign firms to move in there. This, in turn, may be a challenge regarding the wage level for the domestic firms. This study, however, does not address this question.

The analysis also demonstrates a strong correlation between RLAis and wages in the regions exhibiting strengths in manufacturing industries. Results of the multivariate regression analysis are significant at the $\mathrm{p}<.05$ level. This can be an indication of the attraction of resource and efficiency seeking investment in the manufacturing-focused industries into the regions. In addition to wage and RLAis correlation and for the robustness check where the wages and market size correlation is reported in Appendix 2. This correlation supports the earlier findings and accentuates the strength of correlation between RLAis and wages in regions with higher service industry specialization measure for financial intermediation sector in Mazowieckie region with correlation coefficient at 0.035 levels.

Following the previous findings concluding that foreign investors entering a host economy tend to innovate more, the results of the test presented in the Appendix 3 show the correlation coefficient between industrial specialization for foreign investment and investment in $R \& D$ is demonstrating strong relationship measures for a number of manufacturing industries in a range of regions at the $p<.05$ level which can be a predictor of the attraction of same or related types of investment into those regions. This result can also be an indicator that in addition to providing investment foreign firms may also serve as the source of knowledge and know-how for those regions going forward. Such type of investment in $\mathrm{R} \& \mathrm{D}$, especially at the early stage of the economic transition can be very effective and drive its future success (Djankov and Hoekman,2000). The regions able to attract a higher concentration of foreign investors are also expected to have a higher level of R\&D investment in them which also supports H4. Such, for example, are Zachodniopomorskie in manufacturing of chemicals with multiple regression measure at and 0.612 , or Malopolskie in manufacturing of rubber and plastics with correlation coefficient at 0.751 for the period.

Further, the results of this study support the earlier findings relating to emerging regions in the Eastern border of Poland. Similarly, to the study of Crescenzi and Iammarino (2016) we see that an increasing share of foreign direct investment from Western Europe which previously was targeting the periphery of the EU, or new accessing countries into the Union, has directed it is an investment toward the markets outside of the EU. They also concluded that the periphery is losing its attractiveness not only for the European investment but also for foreign investment from outside of Europe. Their study also finds that the declining regions within the peripheral countries of the EU that they call "slippers" are experiencing the most significant change in the nature of the incoming FDI, namely the regions tend to attract less investment in manufacturing-related activities and become more attractive to the services retail and logistics type of activities Crescenzi and Iammarino (2016). The results of this study show that the southwestern regions in Poland are an example of such a trend.

Also, similar to the findings of Blanc-brude et al.(2014) this study finds the attraction of foreign firms to the core economic and administrative regions such as Mazowieckie, capital region. The focus here is on the remaining regions such as peripheral regions in both eastern and western regions of Poland which exhibit potential for the attraction of new investment seeking skilled workforce and those that have positioned themselves to attract FDI often based on the existing legacy industries. Specifically, regions at the eastern periphery of Poland seem to offer efficiencies and access to exogenous markets beyond the host country. They are offering opportunities to reach external markets immediately to the east.

Testing if FDI in Poland exhibits an increasing level of industrial specialization in service and manufacturing investments using the outcome of the index the results show that both service and manufacturing oriented FDI seems to narrow their industrial specialization across regions during the examined period. Overall, this study finds that the hypothesis tested here show that only regions with ample human capital, and therefore also markets, such as Małopolskie, Mazowieckie, and Wielkopolskie see industries developing concentration of serviceoriented foreign direct investment with RLAis above1, indicating strength of the industrial specialization. 
The use of the regressions methods to test the correlation of the variables however does not provide a clear indication of the direct causation or impact of one variable on the other. This relationship is established by theoretical reasoning and precedent demonstrated by earlier studies. The results for foreign subsidiaries in manufacturing sectors reveal a concentration of manufacturing of transport equipment, metals, chemicals, and food, just to name some, generally locate in regions with the established presence of legacy industries for specific regions, such as Malopolskie. Additionally, most regions across Poland that developed industrial specialization strength are also able to attract a higher grade of foreign direct investment in the same or related industries.

The method and the data used also presents some limitations use of specific variables. The period studied here offers potentially limited insights; however these insights are important as they reveal the sensitivity of the immediate effect of the policy and system change, which in a longer period study might be lost. Additionally they DID method provides us with the before and after picture of the impact of the EU accession on the FDI flows into Poland which supports the earlier findings.

\section{Discussion}

The central focus of this study is on the difference in location patterns of foreign subsidiaries in the developing economy based on the industrial activity of the firms. To answer for the raised hypothesis and determine whether the economic regions in Poland narrow their industrial specialization based on manufacturing and service criteria the data on the location of foreign firms in several participating industries in each sector present in the regions is used. The presented empirical analysis tests whether FDI locating in Poland exhibits an increasing level of service focused investment. Also, it tests if industrial specialization of regions attracts new foreign investors in the narrowing industrial sectors in the regions. The contribution of the analysis presented here helps to answer if the regions attracting more service-related FDI also maintain or increase their presence of foreign firms in manufacturing sectors and whether regions with a high industrial specialization index level of FDI also see an increase in R\&D investment in them. This transition to the common European market has augmented some industrial specialization of regions by transforming the existing industries and bringing new knowledge, technology and know-how expected to be derived from the foreign investment. This can be observed by increased investment in both private and public R\&D spending data. Finally, the impact of the industrial specialization of the regions on an increased level of $R \& D$ investment is present here.

Another significant contribution of this paper is that the cost of the workforce in key regions does not seem to deter investors who could establish their operations in regions within the country at a lower cost and continue to benefit from lower labor cost and other potential advantages. This finding can be an indication that the investing firms seek knowledge and skill that offer the absorptive capacity to move their operations forward. The results of the study reveal the industrial heterogeneity of the regions across Poland immediately before and after the transition into the EU membership. The future study of the later period can provide further evidence of this matter.

Another significant finding here is that the RLAis index measure increase in service industry oriented investment is only visible from the results of the analysis in Mazowieckie and Malopolskie regions. A high population and high level of academic institutions present in those regions may explain this. Moreover, the industrial specialization in the service industry is specifically evident in the Mazowieckie region despite the highest cost of labor. Here the majority of the regions, however, maintain or show an increased level of foreign firms participating in manufacturing sectors the regions specialize in. Historically the leading regions, of Mazowieckie and Wielkopolskie, had an existing functioning industrial base in their dominant sectors although some tend to augment their industrial specialization focus to a related or service industries often offering support to their manufacturing base in form logistics or financial services, the supporting industries, during the period.

The study shows that the long-run industry growth is higher in locations with a wider range of industrial activities, which suggests that firms benefit from being in more diverse urban environments. These diverse agglomerations require scale and necessary resources for industry ecosystem to develop. Additionally, this work shows that small regions are more specialized than larger regions by building their industrial base around fewer industries. The results of this study reveal that some production de-centralizes to smaller, more specialized cities. Such specialization opens an opportunity for less competitive regions to emerge as prospective hosts for FDI activity.

Also, the results for the period show that individual wages are increasing where education level of the workforce is greater. First, the location of foreign firms in service-related 
industries is concentrating nearly exclusively in larger agglomerations with a strong presence of large markets and universities. This seems to indicate that foreign companies in service industries set up their core base of activity in these regions from where they direct sub-regional activities across the country. Second, in this case, the wage level does not seem to be a deterrent for firms to move into regions with higher wage levels. Specifically where there is also a significant amount of competing or complementary economic activity in the region.

Third, for the majority of manufacturing industries, however, attraction to the regions with lower wage levels is, also, observed. In such instances, a substantial number of foreign investors seem to concentrate in the regions with industrial specialization they participate as well.

\section{Conclusion}

This work set out to understand better the dynamics in the location patterns of foreign direct investment subsidiaries in service and manufacturing sectors across regions in Poland prior and immediately after its accession into the EU. As Poland is increasingly sought after location for FDI, the results of this research contribute to the discussion of the raised matter. The results of the analysis show industrial sectors specialization development patterns of foreign subsidiaries based on their industrial classification of activity across all regions of Poland for the period. The findings reveal the economic picture of the geographic distribution of FDI based on the industrial concentration of the foreign firms across Poland as it prepared to enter the EU and immediately afterward. The transition of Poland and its regional economies from the state-run to free market which begun in the early 1990s has accelerated its pace and was significantly augmented by the prospects of joining larger trading block, the EU during the period.

This study contributes to the picture of the location patterns of industrial sectors shown on the example of the developing economy of Poland. It is clear from the results of the analysis presented here that as the result of the anticipated economic openness, accession into the EU, some regions seem to be narrowing existing industrial specialization while other are moving into higher value-added activities and sectors, including service sectors. The findings presented here have strong implication for the decision makers, managers, and investors, in foreign enterprises entering the market. Understanding the location patterns of investment based on
As to the ability to attract new FDI into the regions, especially those showing some industrial specialization remains strong. Both MNCs and local business can benefit from the advantages offered by those regions.

The $R \& D$ spending indicator is another sign of strength where harnessed properly through the relevant absorptive capacity of the regions can lead to independent innovation activity and manifest itself as strength. This result complements the literature on the impact of foreign direct investment flows that have shown the importance of the spillovers from multinational firms to their host locations (Blomstrom and Kokko,1998; Javorcik and Spatareanu,2004; Mironko,2014). This study contributes to the empirical test of the patterns of the foreign direct investment locating across regions in Poland and increasing focus of some regions on service-oriented industries.

the industrial sector of firms allows for an informed decision making for the investors planning to enter a transition economy preparing for a system change, such as entering a large trading block.

After establishing strong industrial specialization, measured by the RLAis index, for some industries regions in collaboration of policy makers and the industry seems to set the conditions for further industrial cluster development.The evident from the data are few of such clusters, developing already during the period as discussed above, for example, Wielkopolskie region.One additional region that is worth to mention here is the Podkarpackie region with its industrial strength in the transportation industry, with the specific focus on the aviation sub-sector. The regional strengths and future development may need to be assessed further in order to make specific policy recommendations tailored to specific locales and industries they are capable of attracting going forward.

The implication of this study for national and regional policymakers would indicate that close collaboration and decision making between them would be useful in determining incoming foreign investment strategy to build on the existing industrial specializations of regions. It is worth noting that regions moving to higher value-added manufacturing and service-related foreign direct investment may further increase the demand on existing skill and potentially increases costs of establishing and running foreign subsidiaries in the most developed regions across Poland. The challenge going forward maybe how to influence the growth of the less developed regions by attracting foreign investment 
into them. The regions can offer sought-after factors for both growth of the investing firm as well as for the local businesses via investment, jobs creation, and knowledge spillovers. This question can be explored by studying the subsequent period.

Besides just corporate network development strategy, ability to attract new firms is a local or regional policy development consideration. The capacity of clusters to develop further and innovate independently is a sign of developing strength. The cluster development strategies for the existing industrial specialization centers across Poland, although viewed broadly here, can be a positive and desired outcome further promoted by a combination of all stakeholders: industry, local, and national economic development actors. As this study looks mainly at industrial specialization across location patterns of FDI immediately before and after the accession into the EU, subsequent research can answer these questions by using data for the later period of economic activity in regions across Poland. This review of the historic period can serve as a lesson for countries transitioning and planning an entry into a larger trading block, such as the EU or similar. The picture presented here shows the result where the anticipation of economic openness may attract foreign investors and consequently support sharper development of industrial specializations within the host economy. The study of the initial period of transition shows signs of tapping into the benefits offered by the opening of the economy to foreign investment.

Appendix 1 Results of regression between RLAis and total labor availability pool

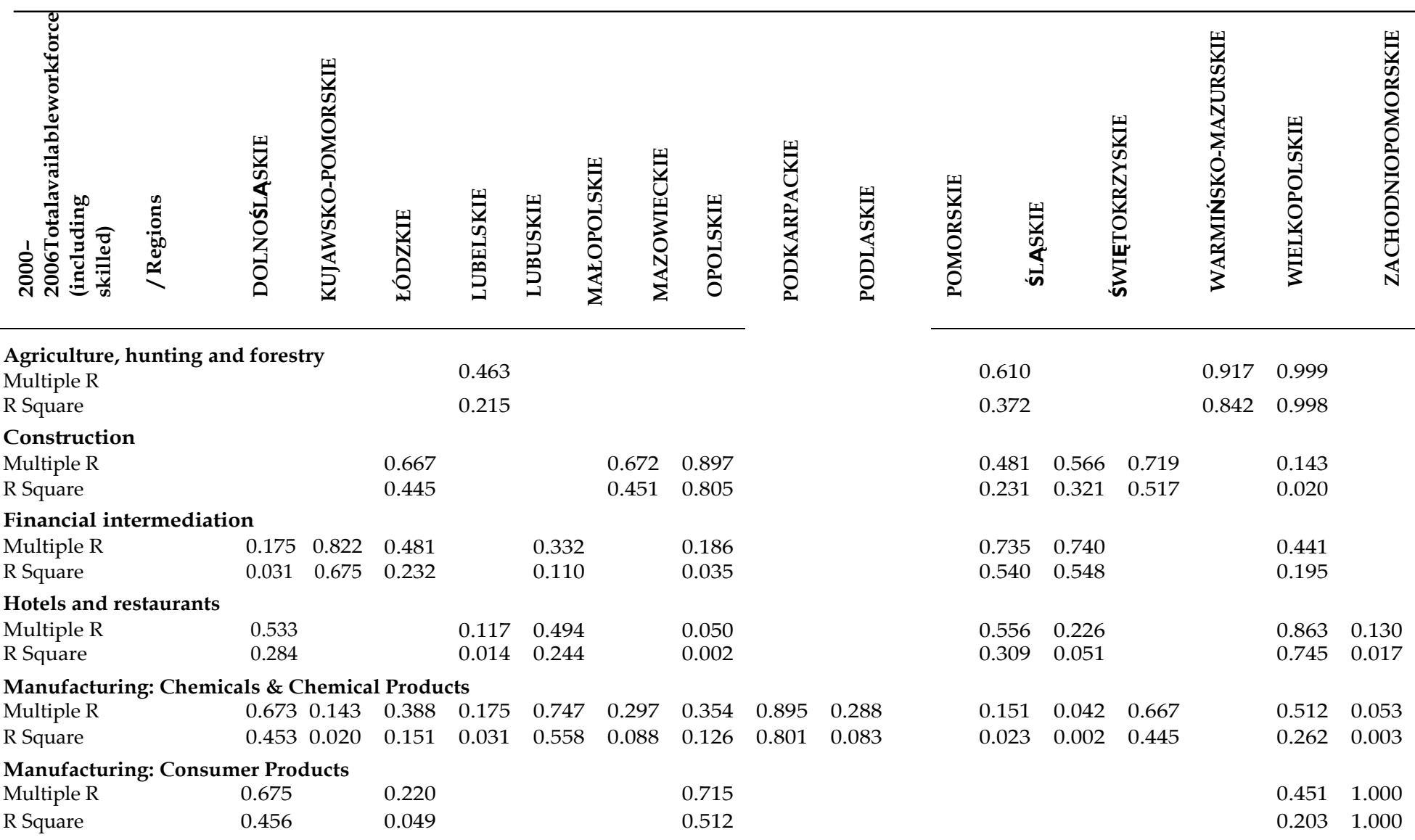


E-ISSN: 2469-6501

VOL: 6, ISSUE: 3

March/2020

CPER DOI:10.33642/fjbass.v6n3p1

https://ijbassnet.com/

\section{(C) Center for Promoting Education and Research (CPER) USA}

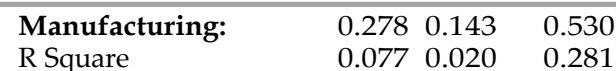

Manufacturing: Fabrics \& Textiles

R Square

$\begin{array}{lll}0.401 & 0.222 & 0.202\end{array}$

0.1600 .049

0.041

Manufacturing: Food, Drinks \& Tobacco Products

Multiple R

$\begin{array}{lll}0.660 & 0.888 & 0.579\end{array}$

$\begin{array}{lll}0.435 & 0.789 & 0.335\end{array}$

0.885

0.784

R Square

ure \& Consumer Goods

Multiple R

$\begin{array}{ll}0.127 & 0.318\end{array}$

0.779

0.607

Manufacturing: Glass

Multiple R

R Square

Manufacturing: Leather \& Leather Products

Multiple R

0.0350 .053

R Square

0.0010 .003

Manufacturing: Machinery \& Equipment

Multiple R

0.210

0.044

$\begin{array}{ll}0.312 & 0.489\end{array}$

R Square

$\begin{array}{ll}0.097 & 0.239\end{array}$

Manufacturing: Metals \& Metal Products

$\begin{array}{lllll}\text { Multiple R } & 0.507 & 0.243 & 0.538\end{array}$

R Square

$\begin{array}{lll}0.257 & 0.059 & 0.290\end{array}$

0.128

0.016

Manufacturing: Other Non-Metal Goods

Multiple R

$0.534 \quad 0.331$

$\begin{array}{ll}0.722 & 0.272\end{array}$

0.2850 .110

$0.521 \quad 0.074$
Multiple R

$0.016 \quad 0.101$

0.524

0.274

$\begin{array}{llll}0.775 & 0.112 & 0.800 & 0.183\end{array}$

0.601

0.013

0.640

$\begin{array}{llll}0.410 & 0.314 & 0.634 & 0.879\end{array}$

$\begin{array}{lll}0.168 & 0.099 & 0.401\end{array}$

0.235

0.055

$\begin{array}{llll} & & & 0.204 \\ & & & 0.041 \\ 0.558 & & & \\ 0.311 & 0.753 & & 0.240 \\ & 0.566 & & 0.058 \\ & & & \\ & 0.835 & 0.200 & \\ & 0.698 & 0.040 & \end{array}$

0.204

0.041

Manufacturing: Pharmaceuticals

Multiple R

0.669

0.448

$\begin{array}{ll}0.057 & 0.491\end{array}$

$0.003 \quad 0.241$

0.759

0.475

0.589

$0.082 \quad 0.303$

$0.007 \quad 0.092$

$\begin{array}{lll}0.723 & 0.508 & 0.148\end{array}$

$\begin{array}{lll}0.522 & 0.258 & 0.022\end{array}$

R Square

0.003

$\begin{array}{lll}0.222 & 0.085 & 0.552 \\ 0.049 & 0.007 & 0.305\end{array}$

WWW.cpernet.org

$\begin{array}{lllll}0.053 & 0.491 & 0.187 & 0.689 & 0.827\end{array}$

0.003

$0.241 \quad 0.035$

$0.474 \quad 0.685$

$\begin{array}{lll}0.846 & 0.728 & 0.225\end{array}$

0.225

0.170

0.456

0.722

$\begin{array}{ll}0.049 & 0.589\end{array}$

$0.486 \quad 0.628$

$0.236 \quad 0.395$

$\begin{array}{lll}0.650 & 0.600 & 0.872\end{array}$

$\begin{array}{lll}0.422 & 0.360 & 0.761\end{array}$

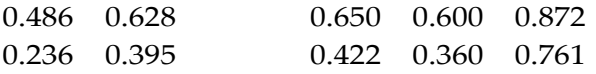

0.570

0.325

Continued 
Appendix1Continued

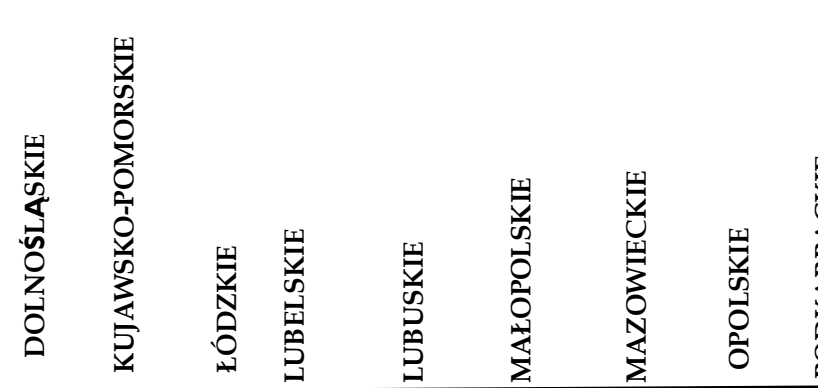

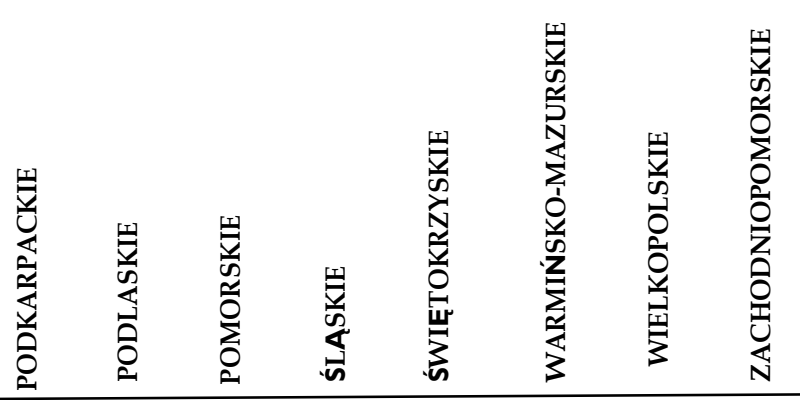

Manufacturing: Pulp \& Paper/Publishing \& Printing

Multiple R

R Square

Multiple R

R Square

$\begin{array}{lllllll}0.423 & 0.094 & 0.084 & 0.820 & 0.646 & 0.355 & 0.088\end{array}$

$\begin{array}{llllllll}0.179 & 0.009 & 0.007 & 0.672 & 0.418 & 0.126 & 0.008\end{array}$

$\begin{array}{ll}0.143 & 0.134 \\ 0.020 & 0.018\end{array}$

Manufacturing: Rubber \& Plastics

\section{Multiple R \\ R Square}

$\begin{array}{lll}0.724 & 0.247\end{array}$

0.5250 .061

$\begin{array}{lllll}0.316 & 0.334 & 0.298 & 0.328 & 0.814\end{array}$

$\begin{array}{lllll}0.100 & 0.111 & 0.089 & 0.108 & 0.663\end{array}$

Equipment

Multiple R

R Square

$\begin{array}{ll}0.847 & 0.080 \\ 0.717 & 0.006\end{array}$

$\begin{array}{lllllll}0.717 & 0.474 & 0.785 & 0.180 & 0.236 & 0.066 & 0.301\end{array}$

$\begin{array}{lllllll}0.714 & 0.225 & 0.617 & 0.032 & 0.056 & 0.004 & 0.090\end{array}$

0.192

0.037

0.146

0.849

0.721

0.282

0.157

0.060

0.004

0.621

0.105

0.011

0.737

0.544

0.147

0.021

$\begin{array}{lll}0.791 & 0.331 & 0.083\end{array}$

$\begin{array}{lll}0.626 & 0.110 & 0.007\end{array}$

0.703

$\begin{array}{lll}0.677 & 0.257 & 0.724\end{array}$

0.494 
Appendix 1 Continued

Manufacturing: Wood \& WoodenProducts

$\begin{array}{lllll}\text { Multiple R } & 0.327 & 0.544 & 0.367 & 0.168 \\ \text { R Square } & 0.107 & 0.296 & 0.134 & 0.028\end{array}$

$0.117 \quad 0.332$

0.0140 .110

Other community, social and personal service activities

Multiple R

$0.610 \quad 0.505$

R Square

0.372

0.255

Real estate, rental and business activities

Multiple R

R Square

$0.654 \quad 0.857$

0.428

0.734

Trade and repair

Multiple R

$\begin{array}{lll}0.799 & 0.059 & 0.302\end{array}$

$\begin{array}{lll}0.639 & 0.004 & 0.091\end{array}$

0.736

0.542

Transport, storage and communication*(2004-2006)

Multiple R

0.541

0.972

0.944

0.293

0.359
0.129

$0.721 \quad 0.399$

$0.520 \quad 0.159$

$\begin{array}{lll}0.409 & 0.871 & 0.404\end{array}$

$\begin{array}{lll}0.167 & 0.759 & 0.164\end{array}$

$\begin{array}{llll}0.513 & 0.983 & 0.560 & 0.871\end{array}$

$\begin{array}{lll}0.965 & 0.313 & 0.759\end{array}$

0.718
0.515

\begin{tabular}{l}
0.665 \\
0.442 \\
\hline
\end{tabular}

0.631

0.399

$\begin{array}{ll}0.366 & 0.921\end{array}$

$0.134 \quad 0.849$

0.058

0.003

$\begin{array}{ll}0.765 & 0.770\end{array}$

0.5850 .593

Source: BasedondataobtainedfromthePolishInformationandForeignInvestmentAgency (PAIIZ)and the author's own analysis. P <.05 
Appendix 2ResultsofregressionbetweenRLAisandmarketsizeandwages
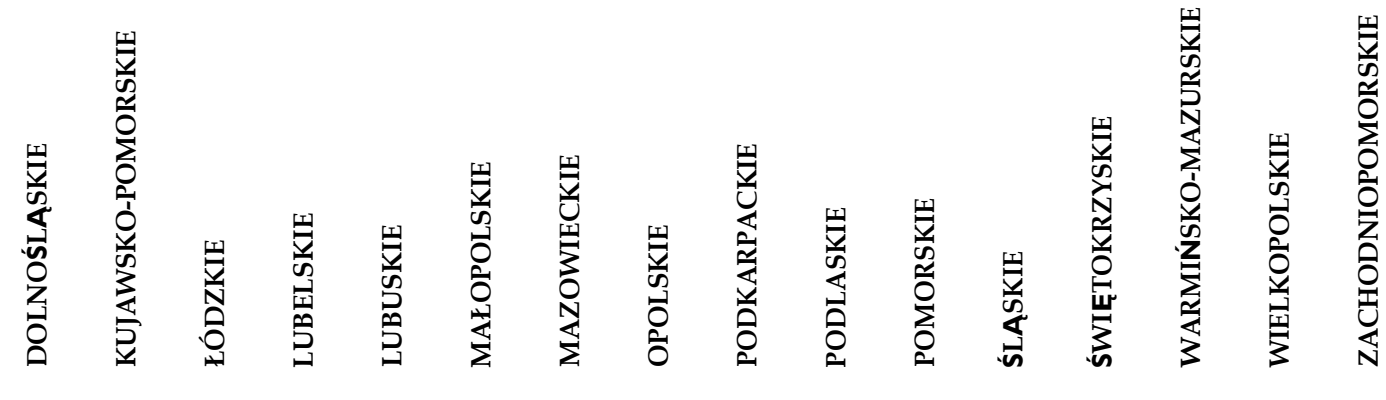

Agriculture, hunting and forestry Multiple R

\section{Construction}

Multiple R

$\mathrm{R}$ Square

1.00

1.00

\subsection{0}

0.63

0.64

Electricity, gas and water supply Multiple R

0.91

R Square

0.84

Financial intermediation

Multiple R

$\mathrm{R}$ Square

0.68

0.46

0.16

$0.03 \quad 0.55$

0.74

0.95

0.90

$\begin{array}{ll}1.00 \quad 0.88 \\ 1.00 & 0.78\end{array}$

$1.00 \quad 0.78$

$\begin{array}{ll}0.78 & 0.47 \\ 0.61 & 0.22\end{array}$

0.99

0.99

\subsection{3}

0.53

Multiple R

R Square

\& Chemical Products

Multiple R

$\mathrm{R}$ Square

$\begin{array}{llll}0.83 & 0.81 & 0.24 & 0.37\end{array}$

$\begin{array}{llll}0.70 & 0.66 & 0.06 & 0.14\end{array}$

$\begin{array}{lllll}0.95 & 0.93 & 0.83 & 0.88 & 0.84\end{array}$

$\begin{array}{llllll}0.91 & 0.86 & 0.68 & 0.77 & 0.71\end{array}$
0.63

0.40

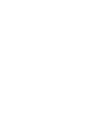

$\begin{array}{ll}0.88 & 0.84\end{array}$

0.87

$0.77 \quad 0.71$

$\begin{array}{llll}0.83 & 0.80 & 0.76 & 0.88\end{array}$

$\begin{array}{llll}0.70 & 0.64 & 0.58 & 0.78\end{array}$

$\begin{array}{llllll}0.96 & 0.84 & 0.79 & 0.73 & 0.90 & 0.43\end{array}$

$\begin{array}{llllll}0.92 & 0.70 & 0.62 & 0.53 & 0.80 & 0.19\end{array}$

$\begin{array}{ll}0.98 & 0.49\end{array}$

$0.95 \quad 0.24$

0.65

0.42

$\begin{array}{ll}0.99 & 0.92\end{array}$

\begin{tabular}{ll}
$0.97 \quad 0.94$ \\
\hline
\end{tabular}

$0.94 \quad 0.88$

$\begin{array}{lll}0.89 & 0.98 & 1.00\end{array}$

$\begin{array}{lll}0.79 & 0.97 & 1.00\end{array}$

$\begin{array}{ll}0.65 & 0.51\end{array}$

$0.42 \quad 0.26$ 
Appendix 2 Continued

Manufacturing: Consumer Products

Manufacturing:

\subsection{7}

0.38

0.15

Manufacturing : Electrical Machinery and Apparatus

Multiple R

R Square

$\begin{array}{lll}0.93 & 0.96 & 0.74\end{array}$

$\begin{array}{lll}0.87 & 0.91 \quad 0.55\end{array}$

Manufacturing: Fabrics \& Textiles

Multiple R

R Square

0.660 .76

0.440 .58

0.57

0.33

Manufacturing: Food, Drinks \& Tobacco Products

Multiple R

$\begin{array}{llll}0.93 & 0.95 & 0.71 & 0.95\end{array}$

R Square

$\begin{array}{llll}0.86 & 0.91 & 0.50 & 0.91\end{array}$

Manufacturing: Furniture \& Consumer Goods

Multiple R

R Square

0.620 .88

$0.38 \quad 0.78$

0.89

0.79

Manufacturing: Glass

Multiple R

R Square

Manufacturing: Leather \& Leather Products

Multiple R

R Square

0.930 .99

0.860 .98

Manufacturing: Machinery \& Equipment

Multiple R

0.99

0.97

$0.53 \quad 0.86$

$0.28 \quad 0.74$

Manufacturing: Metals \& Metal Products

Multiple R

R Square

$\begin{array}{lll}0.79 & 0.81 & 0.91\end{array}$

$\begin{array}{lll}0.63 & 0.66 & 0.83\end{array}$

$0.38 \quad 0.56$

$0.15 \quad 0.31$

0.5
0.30

$\begin{array}{lll}0.55 & 1.00 & 0.73\end{array}$

0.53

0.96

0.91

0.85

0.73

0.94

0.88

0.87

0.75

0.98

0.96

0.80

0.65

$0.92 \quad 0.73$

$0.85 \quad 0.53$

0.15

0.02

0.92

0.85

0.88

0.77

0.82
0.68

0.70

0.49

$0.95 \quad 0.69$

$0.90 \quad 0.48$

0.41

0.17

0.99

0.99

0.90

0.81

0.65

0.86

0.98

$0.96 \quad 0.94$

$0.80 \quad 0.73$

0.920 .89

$0.38 \quad 0.94$

$0.14 \quad 0.88$

Continued 


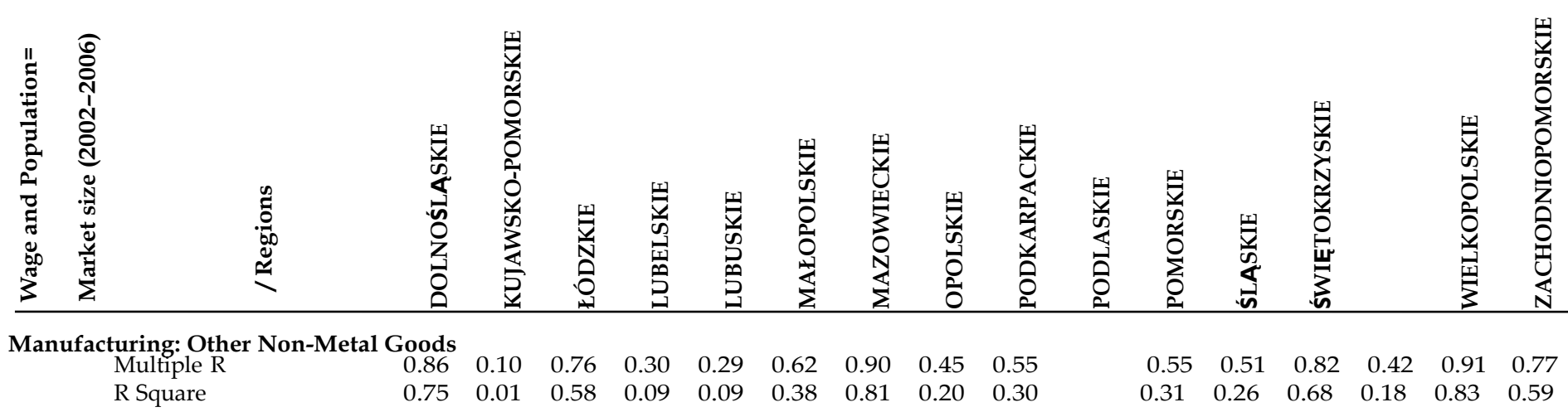

Manufacturing: Pharmaceuticals

Multiple R

0.83

0.68
0.72

0.52
0.84

0.71

Manufacturing: Pulp \&Paper/Publishing \& Printing

Multiple R

$\mathrm{R}$ Square $\begin{array}{lllll}0.98 & 0.94 & 0.88 & 0.97 & 0.82\end{array}$

$\begin{array}{lllll}0.95 & 0.89 & 0.77 & 0.93 & 0.68\end{array}$ $\begin{array}{ll}0.98 & 0.83 \\ 0.96 & 0.69\end{array}$

$0.96 \quad 0.69$
1.00

1.00
0.91

0.96
0.91

0.15

0.76

0.87

0.76

Manufacturing: Radio, Television, Communication Equipment \& Apparatus

Multiple R

R Square

0.96

0.91
0.58

0.34
$0.99 \quad 0.97$

$0.99 \quad 0.94$ $\begin{array}{lllll}0.58 & 0.57 & 1.00 & 0.95 & 0.61\end{array}$

$\begin{array}{lllll}0.34 & 0.32 & 0.99 & 0.91 & 0.38\end{array}$ $\begin{array}{llll}0.86 & 0.95 & 0.76 & 0.85\end{array}$

$\begin{array}{llll}0.74 & 0.91 & 0.58 & 0.73\end{array}$
0.84

0.71

$\begin{array}{lll}0.87 & 0.93 & 0.80\end{array}$

Multiple R
R Square

(1)

(n)

.74

$\begin{array}{lllll}0.58 & 0.73 & 0.76 & 0.86 & 0.63\end{array}$


E-ISSN: 2469-6501

VOL: 6, ISSUE: 3

March/2020

CPER

DOI:10.33642/ijbass.v6n3p1

https://ijbassnet.com/

(C) Center for Promoting Education and Research (CPER) USA

WWW.cpernet.org

Appendix 2 Continued

Manufacturing: Transport Equipment

Multiple R

$\begin{array}{lll}0.97 & 0.52 & 0.97\end{array}$

$\begin{array}{ll}0.87 & 0.57\end{array}$

$\begin{array}{lll}0.94 & 0.27 & 0.94\end{array}$

$\begin{array}{ll}0.75 & 0.33\end{array}$

$\begin{array}{llll}0.55 & 0.89 & 0.87 & 0.87\end{array}$

0.76

0.69

0.72

0.95

0.98

Manufacturing: Wood \& Wooden Products

Multiple R

$0.90 \quad 0.45$

$\begin{array}{ll}0.94 & 0.26\end{array}$

$0.82 \quad 0.20$

$\begin{array}{ll}0.87 & 0.07\end{array}$

$\begin{array}{ll}0.78 & 0.91\end{array}$

$0.61 \quad 0.82$

$\begin{array}{ll}0.81 & 0.89\end{array}$

R Square

1.00

Multiple R

1.00

$\begin{array}{lll}0.91 & 0.98 & 0.72\end{array}$

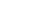

R Square

d personal service activities

Other com
Multiple R

0.90

0.86

0.83

$0.97 \quad 0.52$

0.92

0.85

R Square

0.81

0.75

$\begin{array}{ll}0.93 & 0.72\end{array}$

$0.86 \quad 0.51$

$0.90 \quad 0.90$

$0.50 \quad 0.84$

Real estate, rental and business activities

Multiple R

$0.92 \quad 0.90$
0.85

0.90
0.81

$\begin{array}{lll}0.96 & 0.80 & 0.85\end{array}$

0.82

0.80

$0.25 \quad 0.71$

R Square

0.85

$\begin{array}{lll}0.93 & 0.64 & 0.73\end{array}$

0.89

0.95

0.34

0.79

0.90

$0.12 \quad 0.67$

Trade and repair

Multiple R

$\begin{array}{lllll}0.86 & 0.60 & 0.43 & 0.96 & 1.00\end{array}$

$\begin{array}{lll}0.90 & 0.80 & 0.95\end{array}$

0.86

$0.89 \quad 0.98$

$0.90 \quad 0.82$

$\begin{array}{lllll}0.75 & 0.36 & 0.19 & 0.91 & 1.00\end{array}$

$\begin{array}{lll}0.81 & 0.64 & 0.91\end{array}$

0.73

$0.79 \quad 0.95$

$0.81 \quad 0.66$

Transport, storage and communication*(2004-2006)
Multiple R
1.00
R Square
1.00

Source: Based on data obtained from the Polish Information and Foreign Investment Agency (PAIIZ) and the author's own analysis. P $<.05$ 
Appendix 3Resultsofregressionbetweenregional industrial specialization level and R\&D spending

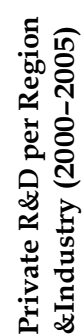

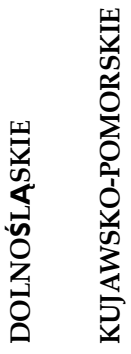

Agriculture, hunting and forestry

Multiple R

R Square
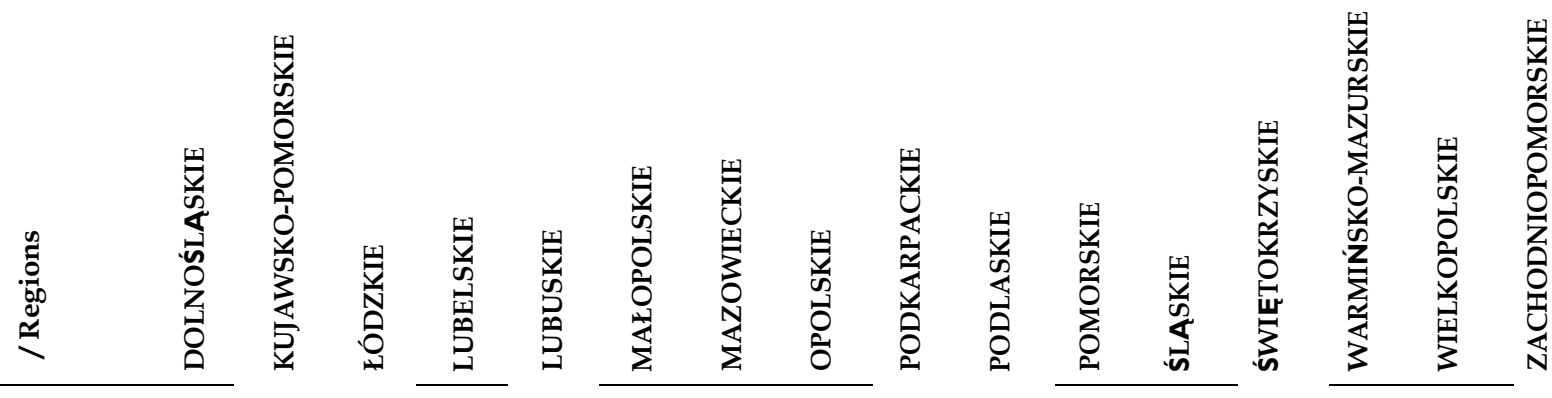

0.075

0.904

$0.263 \quad 0.625$

Mining and quarrying

Multiple R

0.614

0.006

0.816

$\begin{array}{ll}0.069 & 0.391\end{array}$

R Square

0.377

$\begin{array}{lll}0.809 & 0.392 & 0.597\end{array}$

$\begin{array}{lll}0.654 & 0.153 & 0.357\end{array}$

Manufacturing: Chemicals \& Chemical Products

Multiple R

$\begin{array}{lllllllll}0.485 & 0.424 & 0.498 & 0.261 & 0.700 & 0.487 & 0.549 & 0.635 & 0.457\end{array}$

$\begin{array}{lllllllll}0.235 & 0.180 & 0.248 & 0.068 & 0.490 & 0.237 & 0.302 & 0.403 & 0.209\end{array}$

$\begin{array}{lll}0.056 & 0.144 & 0.383\end{array}$

$\begin{array}{ll}0.267 & 0.782\end{array}$

R Square

$0.812 \quad 0.376$

0.659

0.141

0.034

0.001

R Square

and Apparatus

Multiple R

$\begin{array}{lll}0.164 & 1.000 & 0.423\end{array}$

R Square

$\begin{array}{lll}0.027 & 1.000 & 0.179\end{array}$

0.161

0.351

$\begin{array}{ll}0.715 & 0.357\end{array}$

0.652

$\begin{array}{lll}0.003 & 0.021 & 0.146\end{array}$

$\begin{array}{ll}0.071 & 0.612\end{array}$

Manufacturing: Fabrics \& Textiles

Multiple R

$\begin{array}{lll}0.364 & 0.631 & 0.466\end{array}$

0.026

0.123

$\begin{array}{ll}0.511 & 0.128\end{array}$

$0.256 \quad 1.000$

0.0661 .000

$\begin{array}{lll}0.132 & 0.398 & 0.217\end{array}$

$\begin{array}{llll}0.419 & 0.824 & 0.086 & 0.629\end{array}$

0.324

$\begin{array}{llll}0.706 & 0.509 & 0.233 & 0.589\end{array}$

$\begin{array}{lllll}0.176 & 0.679 & 0.007 & 0.396\end{array}$

0.105

$\begin{array}{lllll}0.498 & 0.259 & 0.054 & 0.347\end{array}$ 
E-ISSN: 2469-6501

VOL: 6, ISSUE: 3

March/2020

CPER DOI:10.33642/ijbass.v6n3p1

https://ijbassnet.com/

\section{(C) Center for Promoting Education and Research (CPER) USA}

WwW.cpernet.org

Manufacturing: Food, Drinks \& Tobacco Products

Multiple R

$\begin{array}{lll}0.873 & 0.932 \\ 0.763 & 0.868 & 0\end{array}$

R Square

0.7630 .868

$0.630 \quad 0.841$

$\begin{array}{ll}0.396 & 0.708\end{array}$

Manufacturing: Furniture \& Consumer Goods

Multiple R

$0.553 \quad 0.450$

$0.450 \quad 0.816$

$0.306 \quad 0.202$

0.666

$\begin{array}{llll}0.096 & 0.740 & 0.399 & 0.82\end{array}$

$50.996 \quad 0.801$

$\begin{array}{llllll}0.356 & 0.295 & 0.465 & 0.055 & 0.232 & 0.711\end{array}$

R Square

$\begin{array}{lllllll} & & & & & & 0.045 \\ & & & & & & 0.002 \\ 0.300 & 0.163 & & & & & \\ 0.090 & 0.027 & & 0.303 & 0.021 & & 0.310 \\ & & & & 0.000 & & 0.096 \\ & 0.132 & 0.031 & & 0.717 & 0.206 & \\ & 0.017 & 0.001 & & 0.515 & 0.042 & \end{array}$

0.045

Multiple R

0.002

Manufacturing: Leather \& Leather Products

Multiple R

R Square

$\begin{array}{ll}0.017 & 0.001\end{array}$

0.538

$0.482 \quad 0.758$

$0.232 \quad 0.575$

$\begin{array}{lll}0.209 & 0.305 & 0.080\end{array}$

$\begin{array}{lll}0.044 & 0.093 & 0.006\end{array}$

Manufacturing: Machinery \& Equipment

Multiple R

0.791

$0.515 \quad 0.042$

$\begin{array}{lllll}0.916 & 1.000 & 0.836 & 0.930\end{array}$

R Square

0.626

$\begin{array}{lllllllllllll}0.047 & 0.047 & 0.888 & 0.612 & 0.029 & 0.734 & 0.472 & 0.468 & 0.631 & 0.882 & 0.407 & 0.717 & 0.452\end{array}$

0.3930 .969

Products

Multiple R

0.002

$\begin{array}{lllllllllllll}0.002 & 0.789 & 0.375 & 0.001 & 0.539 & 0.222 & 0.219 & 0.398 & 0.778 & 0.166 & 0.514 & 0.204\end{array}$

0.1540 .938

Manufacturing: Other Non-Metal Goods

Multiple R

$\begin{array}{lllllllll}0.289 & 0.741 & 0.063 & 0.143 & 0.639 & 0.598 & 0.165 & 0.831 & 0.310\end{array}$

$\begin{array}{llllll}0.154 & 0.583 & 0.225 & 0.572 & 0.513 & 0.557\end{array}$

R Square

$\begin{array}{lllllllll}0.084 & 0.549 & 0.004 & 0.020 & 0.408 & 0.358 & 0.027 & 0.690 & 0.096\end{array}$

$\begin{array}{lllllll}0.024 & 0.340 & 0.050 & 0.327 & 0.264 & 0.310\end{array}$

Manufacturing: Pharmaceuticals

Multiple R

R Square

$\begin{array}{ll}0.652 & 0.859 \\ 0.425 & 0.737\end{array}$

0.842

0.709 
E-ISSN: 2469-6501

VOL: 6, ISSUE: 3

March/2020

CPER DOI:10.33642/ibass.v6n3p1

https://ijbassnet.com/

\section{(C) Center for Promoting Education and Research (CPER) USA}

WwW.cpernet.org

Electricity, gas and water supply Multiple R

R Square

0.567

0.321

Construction

Multiple R

R Square

Trade and repair

Multiple R

$\mathrm{R}$ Square

Hotels and restaurants

Multiple R

R Square

Financial intermediation

Multiple R

R Square

Real estate, rental and business activities

Multiple R 0.561

R Square

0.315

0.917

\subsection{8}

0.720

$\begin{array}{llllllll}0.000 & 0.911 & 0.307 & 0.547 & 0.361 & 0.952 & 0.664 & 0.102\end{array}$

$\begin{array}{llllllll}0.000 & 0.829 & 0.094 & 0.299 & 0.130 & 0.905 & 0.441 & 0.010\end{array}$

$\begin{array}{llllll}0.401 & & & 0.253 & 0.414 & 0.499 \\ 0.161 & & & 0.064 & 0.171 & 0.249 \\ & & & & & \\ 0.094 & 0.537 & 0.656 & & 0.196 & 0.466 \\ 0.009 & 0.289 & 0.430 & & 0.039 & 0.217\end{array}$

Other community, social and personal service activities

Multiple R

$0.018 \quad 0.066$

R Square

0.000
0.2310 .394

0.0530 .156

$\begin{array}{lll}0.408 & 0.220 & 0.528\end{array}$

$\begin{array}{lll}0.166 & 0.049 & 0.279\end{array}$

$0.693 \quad 0.692$

0.4810 .478 $\begin{array}{llllllll}0.280 & 0.055 & 0.728 & 0.566 & 0.737 & 0.327 & 0.171 & 0.194\end{array}$

$\begin{array}{llllllll}0.078 & 0.003 & 0.530 & 0.320 & 0.543 & 0.107 & 0.029 & 0.038\end{array}$

\begin{tabular}{|c|c|c|c|c|c|}
\hline & 0.611 & 0.313 & 0.501 & 0.912 & \\
\hline & 0.373 & 0.098 & 0.251 & 0.832 & \\
\hline 0.441 & & 0.308 & 0.676 & 0.494 & 0.907 \\
\hline 0.194 & & 0.095 & 0.457 & 0.244 & 0.823 \\
\hline & 0.553 & 0.135 & & 0.559 & 0.889 \\
\hline & 0.306 & 0.018 & & 0.313 & 0.790 \\
\hline & 0.301 & 0.083 & & 0.164 & \\
\hline & 0.091 & 0.007 & & 0.027 & \\
\hline & 0.435 & 0.048 & & 0.389 & 0.309 \\
\hline & 0.190 & 0.002 & & 0.151 & 0.095 \\
\hline
\end{tabular}

$0.090 \quad 0.652$

$0.008 \quad 0.425$

$\begin{array}{lll}0.386 & 0.874\end{array}$

$0.149 \quad 0.764$

Source: Based on data obtained from the Polish Information and Foreign Investment Agency (PAIIZ) and the author's own analysis. P <.05 


\section{Bibliography}

Alcácer, J. (2006). Location choices across the value chain: How activity and capability influence collocation. Management Science, 52(10), 1457-1471.

Arikan, A. T. (2009). Inter-firm knowledge exchanges and the knowledge creation capability of clusters. Academy of Management Review, 34(4), 658-676.

Bevan, A. A. and Estrin, S. (2004). "The determinants of foreign direct investment into European transition economies." Journal of Comparative Economics, Vol. 32, No. 4: 775-787.

Blanc-Brude, F., Cookson, G., Piesse, J., \& Strange, R. (2014). The FDI location decision: Distance and the effects of spatial dependence. International Business Review, 23(4), 797-810.

Blomstrom, M. (1991). "Host country benefits of foreign investment." NBER Working Paper No. W3615 (February), Available at SSRN: http://ssrn.com/ abstract=268197.

Blomström, M., \& Kokko, A. (1998). Multinational corporations and spillovers. Journal of Economic surveys, 12(3), $247-277$.

Blomström, M., Kokko, A., \& Mucchielli, J. L. (2003). The economics of foreign direct investment incentives. In Foreign direct investment in the real and financial sector of industrial countries (pp. 37-60). Springer, Berlin, Heidelberg.

Blomström, Magnus. "Study on FDI and regional development." (2006).

Blonigen, B. A., Davies, R. B., Waddell, G. R., \& Naughton, H. T. (2007). FDI in space: Spatial autoregressive relationships in foreign direct investment. European Economic Review, 51(5), 1303-1325.

Botrić, V., \& Škuflić, L. (2006). Main determinants of foreign direct investment in the southeast European countries. Transition Studies Review, 13(2), 359-377.

Bristow, G. (2005). Everyone's a 'winner': problematising the discourse of regional competitiveness. Journal of Economic Geography, 5(3), 285-304.

Cano-Kollmann, M., Cantwell, J., Hannigan, T. J., Mudambi, R., \& Song, J. (2016). Knowledge connectivity: An agenda for innovation research in international business. Journal of International Business Studies, 47(3), 255-262.

Cantwell, J. A. (1989). Technological Innovation and Multinational Corporations. Oxford: Blackwell.

Cantwell, J. A. (1991). "The international agglomeration of R\&D," in M. Casson (ed.), Global Research Strategy and International Competitiveness. Oxford: Blackwell.

Cantwell, J., \& Piscitello, L. (2002). The location of technological activities of MNCs in European regions: The role of spillovers and local competencies. Journal of International Management, 8(1), 69-96.

Cassimati, A. A. (2003, June). The EU and regional reform in Greece. In Workshop III: Greece and the EU.

Chidlow, A., Salciuviene, L., \& Young, S. (2009). Regional determinants of inward FDI distribution in Poland. International business review, 18(2), 119-133.

Cooke, P. (2001). Regional innovation systems, clusters, and the knowledge economy. Industrial and corporate change, 10(4), 945-974.

Cowan, R., \& Jonard, N. (2004). Network structure and the diffusion of knowledge. Journal of economic Dynamics and Control, 28(8), 1557-1575.

Crescenzi, R., \& Iammarino, S. (2016). Global investments and regional development trajectories: the missing links. Regional Studies, 51(1), 97-115.

De Simone, E., \& D’Uva, M. (2016). Social Support, Industrial Parks and FDI Location Choice Across Hungarian Counties. Social Indicators Research, 1-15. 
Djankov, S., \& Hoekman, B. (2000). Foreign investment and productivity growth in Czech enterprises. The World Bank Economic Review, 14(1), 49-64.

Dunning, J. H. (1977). Trade, location of economic activity and the MNE: A search for an eclectic approach. In The international allocation of economic activity (pp. 395-418). Palgrave Macmillan UK.

Dunning, J. H., \& Lundan, S. M. (2008). Multinational enterprises and the global economy. Edward Elgar Publishing.

Dunning, J. H., \& Narula, R. (2005). Multinationals and industrial competitiveness: A new agenda. Edward Elgar Publishing. Ellison, G. and Glaeser, E. L. (1997). "Geographic concentration in U.S. manufacturing industries: a dartboard approach." Journal of Political Economy, Vol. 105, No. 5, 879-927.

Ergas, H. (1986). "Does technology policy matter?" CEPR Conference, London.

Feldman, M., Francis, J., \& Bercovitz, J. (2005). Creating a cluster while building a firm: Entrepreneurs and the formation of industrial clusters. Regional studies, 39(1), 129-141.

Florida, R. (2005). Cities and the creative class. Routledge.

Fujita, M. and Krugman, P. (2004). "The new economic geography: past, present and the future." Papers in Regional Science, Vol. 83: 139-164.

Hanson, G. H. (2001). Scale economies and the geographic concentration of industry. Journal of Economic Geography, 1(3), 255-276.

Head, K., Ries, J., \& Swenson, D. (1995). Agglomeration benefits and location choice: Evidence from Japanese manufacturing investments in the United States. Journal of international economics, 38(3-4), 223-247.

Henderson, V., Kuncoro, A., \& Turner, M. (1995). Industrial development in cities. Journal of political economy, 103(5), 1067-1090.

Iammarino, S., \& McCann, P. (2006). The structure and evolution of industrial clusters: Transactions, technology and knowledge spillovers. Research policy, 35(7), 1018-1036.

Javorcik, B. S., \& Spatareanu, M. (2004). Do foreign investors care about labor market regulations?

Jones, J., \& Wren, C. (2016). Does service FDI locate differently to manufacturing FDI? A regional analysis for Great Britain. Regional Studies, 50(12), 1980-1994.

Krugman, P. (1991). "Increasing returns and economic geography.” Journal of Political Economy, Vol. 99: 483-499.

Lewin, A. Y., Massini, S., \& Peeters, C. (2009). Why are companies offshoring innovation? The emerging global race for talent. Journal of International Business Studies, 40(6), 901-925.

Li, P. and Harald B. (2017). "Location strategy in cluster networks." Journal of International Business Studies: 1-23.

Lipsey, R. E. and Kravis, I. B. (1985). “The competitive position of U.S. manufacturing firms.” NBER Working Paper Series, January 1985.

Lipsey, R. E., \& Sjoholm, F. (2001). Foreign direct investment and wages in Indonesian manufacturing (No. w8299). National Bureau of Economic Research.

Markusen, J. R., Rutherford, T. F., \& Tarr, D. (2000). Foreign Direct Investments in Services and the Domestic Market for Expertise (No. w7700). National Bureau of Economic Research.

Marshall, A. (1920). Principles of Economics (8th edn.). London: Macmillan.

Megginson, W. L., \& Netter, J. M. (2001). From state to market: A survey of empirical studies on privatization. Journal of economic literature, 39(2), 321-389.

Mickiewicz, T., \& Baltowski, M. (2003). All roads lead to outside ownership: Polish piecemeal privatization. International Handbook on Privatization, 402.

Miles, I. (2005). Knowledge intensive business services: prospects and policies. Foresight, 7(6), 39-63. 
Mironko, A. (2014). Determinants of FDI Flows within Emerging Economies: A Case Study of Poland. Springer. Mironko, A. (2018). The Impact of Human Capital and Skill Availability on Attraction of Foreign Direct Investment (FDI) Into Regions within Developing Economies, International Journal of Management, 9 (3), pp. 139- 163.

Noorbakhsh, F., Paloni, A., \& Youssef, A. (2001). Human capital and FDI inflows to developing countries: New empirical evidence. World development, 29(9), 1593-1610.

Porter, M. E. (1992). Capital choices: Changing the way America invests in industry. Journal of Applied Corporate Finance, 5(2), 4-16.

Porter, M. E. (2000). Location, competition, and economic development: Local clusters in a global economy. Economic development quarterly, 14(1), 15-34.

Resmini, L. (2000). The determinants of foreign direct investment in the CEECs: New evidence from sectoral patterns. Economics of transition, 8(3), 665-689.

Rugman, A. M., \& Verbeke, A. (2003). Extending the theory of the multinational enterprise: Internalization and strategic management perspectives. Journal of International Business Studies, 34(2), 125-137.

Sass, M., \& Fifekova, M. (2011). Offshoring and outsourcing business services to Central and Eastern Europe: Some empirical and conceptual considerations. European Planning Studies, 19(9), 1593-1609.

Saxenian, A. (1994). Regional networks: industrial adaptation in Silicon Valley and route 128.Saxenian, A. (1994). Regional networks: industrial adaptation in Silicon Valley and route 128.

Schäffler, J., Hecht, V., \& Moritz, M. (2016). Regional determinants of German FDI in the Czech Republic: new evidence on the role of border regions. Regional Studies, 1-13.

Sinn, H. W. (2004). The new systems competition. Perspektiven der Wirtschaftspolitik, 5(1), 23-38.

Soete, L. (1987). "The impact of technological innovation on international trade patterns: the evidence reconsidered." Research Policy, Vol. 16, No. 2-4, (August): 101-130.

Stark, D. (1996). Recombinant property in East European capitalism. American journal of sociology, 101(4), 993-1027.

Tsai, W. (2001). Knowledge transfer in intraorganizational networks: Effects of network position and absorptive capacity on business unit innovation and performance. Academy of management journal, 44(5), 996-1004.

Venables, A. J. (1996). Equilibrium locations of vertically linked industries. International economic review, 341-359.

The UNCTAD 2015 Annual Report 